The appearance of $\gamma$-amino-butyric acid at the stage corresponding to deposition of the solid endosperm and its apparently increasing concentration in the liquid endosperm with increasing maturity of the nut suggest that this amino-acid arises as a result of some reaction connected with protein synthesis. A full account of this work will be published elsewhere.

I thank Dr. R. L. M. Synge and Prof. F. C. Steward for authentic samples of $\gamma$-amino-butyric acid; and Mr. B. P. M. Perera for technical assistance.

Department of Physiology,

N. G. Baptist

Faculty of Medicine,

University of Ceylon. Oct. 2.

'Steward, F. C., Thompson, D. F., and Dent, C. E., Science, 110, 439 (1949).

${ }^{2}$ Hulme, A. C., and Arthington, W., Nature, 165, 716 (1950).

${ }^{3}$ Westall, R. G., Nature, 165, 717 (1950).

${ }^{4}$ Reed, I. J., J. Biol. Chem. 183, $451(1950)$.

'Woiwood, A. J., and Proom, H., J. Gen. Microbiol., 4, 501 (1950).

- Awapara, J., Landua, A. J., Fuerst, R., and Seale, B., J. Biol. Chem., 187,35 (1950).

'Boulanger, P., and Biserte, G., C.R. Acad. Sci., Paris, 233, 1498

- Crumpler, H. R., and Dent, C. E., Nature, 164, 441 (1949).

- Levy, A. L., and Chung, D., Anal. Chem., 25, 396 (1953).

\section{Selective Destruction of Mesenchyme in Tissue Culture by the $\alpha$-Toxin of Clostridium welchii Type $A$}

THE $\alpha$-toxin of the gas-gangrene organism Clostridium welchii type $A$ is one of the few lethal toxins of known enzymic action; it is a lecithinase $C$, which splits lecithin into phosphoryl choline and a diglyceride ${ }^{1}$. It affects the enzymic activity of isolated mitochondria and lyses red blood cells ${ }^{3}$. Unfractionated welchii toxin caused histological changes in fragments of tissues and organs, including the release of fat globules, lysis of nuclei, and general break-up, that agreed more or less with the clinical picture ${ }^{4}$, and destroyed guinea pig spleen in cultur $\theta^{5}$.

In the present experiments, explants, about $1 \mathrm{~mm}$. across, of the organs of chick embryos (6-13 day) were exposed to various dilutions of the toxin for $30 \mathrm{~min}$. at $38^{\circ} \mathrm{C}$, washed, and grown in clot of plasma and embryo extract as 'hanging-drop' cultures.

Untreated explants from most organs produced an outgrowth of fibroblasts and wandering cells. If the organ contained epithelium, whether and how soon the latter grew out depended partly on its relations to the surface of the explant; if any epithelium appeared in the zone of growth, it was usually overgrown in subculture by fibroblests. It was found that in some concentrations the toxin would eliminate the fibroblasts and wandering cells from the outgrowth of many organs, including lung, mesonephros, metanephros, thyroid, pancreas, and gut, and leave the epithelium flourishing. Stained sections of rather larger explants that had been grown by the watchglass method showed that the internal mesenchyme had been killed. The results with lung were especially striking, for after the connective-tissue stroma had been destroyed, the unfettered bronchial system was able to unfold. In the absence of connective tissue, the epithelial cells became disarranged, and after two days the tubules had given place to sheets, strands, and small vesicles. Cell division was very common, and subculture yielded pure epithelium.
The range of concentration over which the mesenchyme and the epithelium were killed varied from organ to organ. Thus, some of the mesenchyme of the metanephros was able to withstand exposure to $100 L D 50$ (mouse)/ml. (1 r.U. $\alpha$-antitoxin neutralized about $25 L D 50$ ), whereas that of lung was completely destroyed at $10 \mathrm{LD} 50 / \mathrm{ml}$. Much of the epithelium of the lung survived after the standard 30 -min. treatment with $1,000 \mathrm{LD} 50 / \mathrm{ml}$; ; and that of the metanephros was still more resistant, some of it not being killed when grown in a medium that initially contained this concentration. In contrast, $10 \mathrm{LD} 50$ / $\mathrm{ml}$. was lethal to both components of skin, though $1 L D 50 / \mathrm{ml}$. left them healthy.

Differential sensitivity was shown also by foetal rat lung (17-day); a few fibroblasts grew out after exposure to $100 \mathrm{LD} 50 / \mathrm{ml}$., but pure epithelial cultures were obtained after $1,000 \mathrm{LD} 50 / \mathrm{ml}$.

The differential effect was still produced by the lecithinase after the traces of other toxins present had been inactivated by specific antisera.

This lecithinase may prove a useful tool for obtaining pure cultures of epithelium. The methods so far available for this purpose have depended on the selective inhibition of mesenchymal growth, except in those organs in which the two components are readily separable; whereas the lecithinase actually kills the mesenchyme selectively. For preparative work, a comparatively crude toxin would be adequate.

It is not yet clear how these results are related to those of Davidson and Waymouth?, who found that the lecithinase $A$ of snake venom changed the appearance of the cells in explant chick heart from elongated to polyhedral.

I should like to thank Dr. H. B. Fell and Dr. W. Jacobson for their most helpful interest in this work, Dr. M. G. Macfarlane for providing purified toxin, Miss M. Barr of the Wellcome Laboratories for antisera and a further supply of toxin, and Mr. A. J. May and Mr. W. J. Randles for their assistance.

Strangeways Research Laboratory, B. M. ShafFer

Cambridge,

and Microbiological Research

Establishment,

Porton, Wilts.

1 Macfarlane, M. C., and Knight, B. C. J. G., Biochem. J., 85, 884 (1941).

${ }^{2}$ Macfarlane, M. G., and Datta, N., Brit. J. Exp. Path., 85, 191 (1954).

${ }^{3}$ Macfarlane, R. G., Oakley, C. L., and Anderson, C. G., J. Path. Bact., $\mathbf{5 2 , 9 9}(1941)$.

- Frazer, A. C., Flkes, J. J., Sammons, H. G., Govan, A. D. T., and Cooke, W. T., Lancet, i, 457 (1945).

' Lasfargues, E., and Delaunay, A., Inst. Pasteur Ann., 72, 38 (1946).

' Fell, H. B., and Robison, R., Biochem. J., 23, 767 (1929).

'Davidson, J. N., and Waymouth, C., Quart. J. Exp. Physiol., 33, 19 (1944).

\section{Preservation of Corneal Endothelium by Freezing}

THE report ${ }^{1}$ that spermatozoa from several species could be protected from the harmful effects of freezing by the addition of glycerol to the medium opened the way to the preservation for indefinite periods of a wide variety of mammalian tissues. An attempt to include the human cornea in this list ${ }^{2}$ was only partially successful. It was suggested that the lack of complete success was due to the failure of the glycerol-saline technique to protect the corneal endothelium. It was therefore decided to investigate directly the effect of this treatment on the corneal endothelium of the rabbit. 